\title{
Spontaneous regression of metastatic renal cell carcinoma:
}

\section{case report}

\author{
Katerina Lekanidi ${ }^{1}$, Paraskevi A Vlachou*2, Bruno Morgan² and \\ Subramaniam Vasanthan ${ }^{3}$
}

\author{
Address: ${ }^{1}$ Department of Medicine, Leicester Royal Infirmary, Leicester, LE1 5WW, UK, ${ }^{2}$ Department of Radiology, Leicester Royal Infirmary, \\ Leicester, LE1 5WW, UK and '3Department of Oncology, Leicester Royal Infirmary, Leicester, LE1 5WW, UK \\ Email: Katerina Lekanidi - klekanidi@hotmail.com; Paraskevi A Vlachou* - paraskevi.vlachou@uhl-tr.nhs.uk; \\ Bruno Morgan - bruno.morgan@uhl-tr.nhs.uk; Subramaniam Vasanthan - subramanian.vasanthan@uhl-tr.nhs.uk \\ * Corresponding author
}

Published: 18 September 2007

Received: 18 June 2007

Journal of Medical Case Reports 2007, I:89 doi: 10.1 I86/I752-1947-I-89

Accepted: 18 September 2007

This article is available from: http://www.jmedicalcasereports.com/content/I///89

(c) 2007 Lekanidi et al; licensee BioMed Central Ltd.

This is an Open Access article distributed under the terms of the Creative Commons Attribution License (http://creativecommons.org/licenses/by/2.0), which permits unrestricted use, distribution, and reproduction in any medium, provided the original work is properly cited.

\section{Case presentation}

A 60 year old man, who was under regular haematological follow-up because of myelofibrosis, presented at a routine clinic visit complaining of increasing shortness of breath, weight loss and lethargy. Clinical examination of the chest was normal but a chest $\mathrm{x}$-ray (CXR) showed multiple lung lesions consistent with metastatic deposits (figure 1). A staging computed tomography (CT) scan done shortly afterwards showed marked splenomegaly, causing displacement of the left kidney medially. In the left kidney, there was a $5 \mathrm{~cm}$ soft tissue mass arising from the middle of the kidney with characteristics of primary renal cancer (figure 2). The staging CT chest showed multiple pulmonary metastases in both lungs.

The patient underwent laparoscopic cytoreductive nephrectomy without complications and agreed to have immunotherapy with alpha-interferon. Histology revealed clear cell renal cell carcinoma. Six weeks following the operation, just prior to commencing immuno- therapy, he attended the haematology clinic as routine follow-up. His initial symptoms had completely resolved and a repeat chest radiograph on that day showed clear lungs with no evidence of metastatic deposits (figure 3 ). Although no histological confirmation of the metastatic nature of the lung lesions was obtained, it is highly likely that his pulmonary metastases had regressed spontaneously as the patient had not received any immunotherapy in the meantime. The patient remains well five months after the operation.

Renal cell cancer accounts for $2 \%$ of all cancers and its incidence is steadily rising. It usually presents in late adult life and is more common in males than females. Although they are associated with Von Hippel-Lindau disease, adult polycystic kidney disease and multicystic nephroma, most renal cell cancers develop spontaneously [1].

The patient may present with urological symptoms such as haematuria or flank pain or with an abdominal mass or 


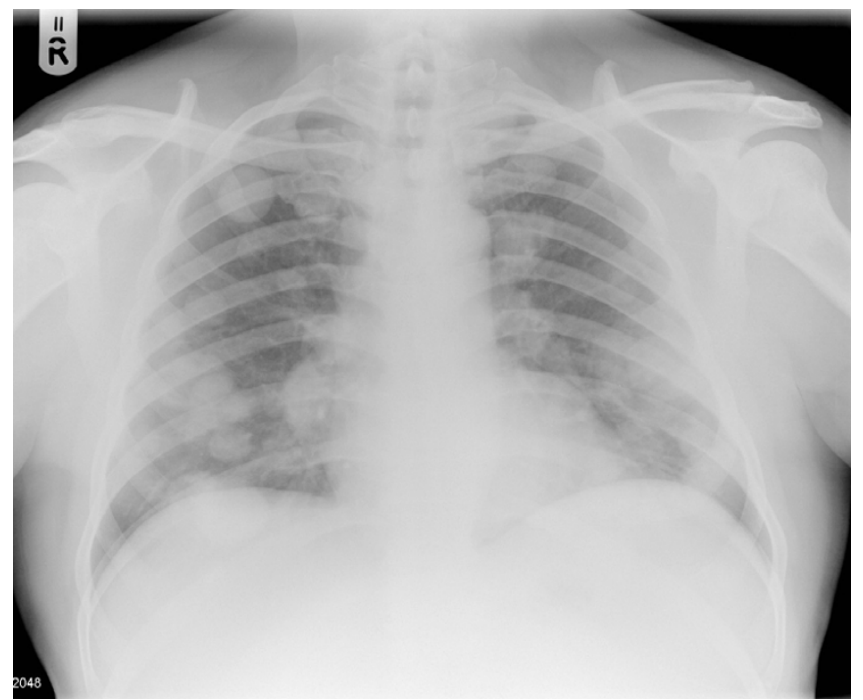

Figure I

CXR showing multiple bilateral lung metastases at diagnosis.

alternatively with systemic manifestations, such as anaemia and fever, or symptoms of metastatic disease and other rare phenomena [2].

Approximately $20 \%$ to $30 \%$ of patients with renal cell carcinoma present with metastatic disease, and $20 \%$ to $40 \%$ of patients undergoing nephrectomy for clinically localized disease will develop metastasis [3]. If the tumor cannot be completely resected, the course is generally relentlessly progressive, with median survival of 12 to 18

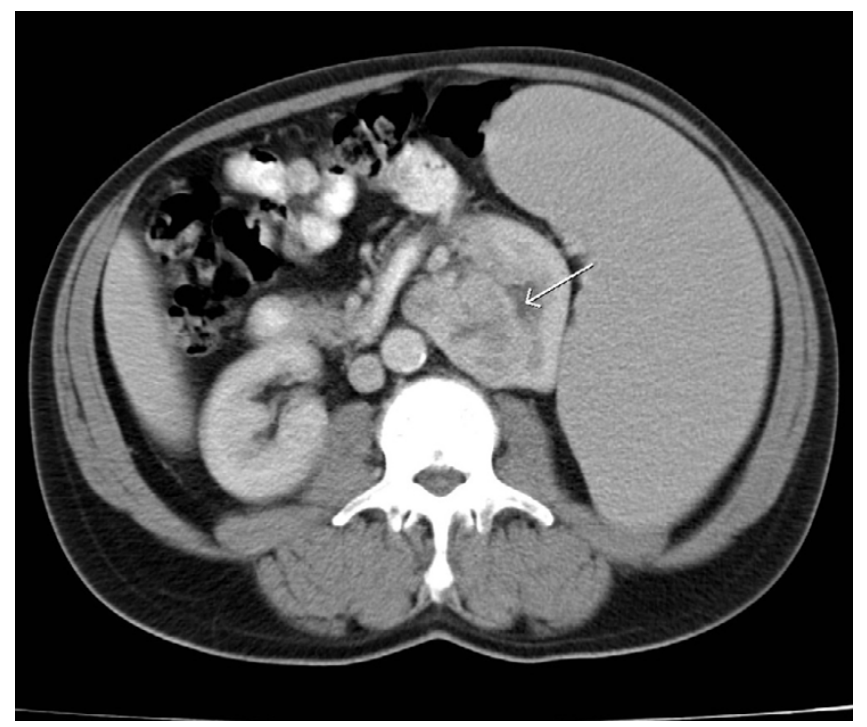

\section{Figure 2}

CT showing a left renal carcinoma (white arrow) and splenomegaly.

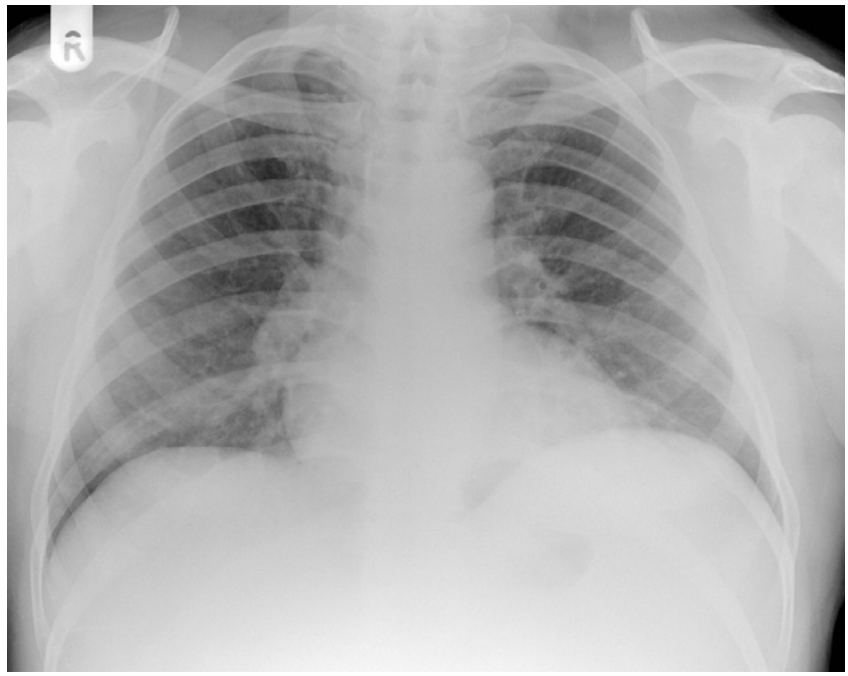

Figure 3

CXR showing no evidence of lung metastases at six weeks after nephrectomy.

months after metastasis. $85 \%$ of relapses occur in the first three years [4].

However, a group of patients with advanced disease have experienced improvements in survival, which is partly related to the introduction of immunotherapeutic approaches and a better understanding of the role and timing of cytoreductive nephrectomy. Although the benefits of immunotherapy have been displayed repeatedly by several studies, controversy has existed as to the need for adjunctive nephrectomy in treating metastatic patients. Removal of the malignant kidney may be of palliative benefit in some settings of metastatic renal cell carcinoma [5]. There have been studies to demonstrate that the benefits of nephrectomy are in addition to and probably greater than the benefit resulting from the interferonalpha that all patients would receive. Others argue that immunotherapy as a modality has had disappointingly little proven impact on the survival of patients with advanced renal cell carcinoma compared to a variety of other options with less toxicity [6].

There have been case reports in the literature that describe spontaneous regression of metastatic renal cancer $[2,7$ 12].

Bumpus described the first reported case of spontaneous regression of metastatic renal cell carcinoma in 1928 [7]. Metastatic sites include brain, bone, hilar adenopathy and most commonly pulmonary metastases. The clinical pattern of the improvement is not uncommonly the complete disappearance of disease, and often the regression is long-lasting. Many of these cases are associated with sur- 
gical removal of the primary tumor, but regression can also occur in association to radiation or embolization of the primary tumor [8].

The rarity of the observation and the heterogeneity of the clinical circumstances in which spontaneous regression of disease occurs do not provide the opportunity for insight into the pathophysiologic mechanism or into the capability for the identification of potential candidates for regression. Although no single mechanism can completely account for this phenomenon, it can be speculated that resection of the primary tumour may result in removal of a prometastatic or growth factor secreted by the tumour and/or promotion of apoptosis might be involved. Immunologic factors almost certainly play a role in some cases of spontaneous tumour regression and perhaps removal of bulk tumour enables or stimulates the immune system to control residual disease. Other theories include hormonal changes, trauma and changes in blood supply (via inhibition of angiogenesis by cytokines) [9].

\section{Conclusion}

It is important to recognize the existence of this clinical entity, which, although rare, might provide another argument in favour of surgical intervention or immunological treatment of metastatic renal cancer. The observation itself should also provide encouragement and drive to pursue immunologic as well as other investigations of the disease.

\section{Competing interests}

The authors declare that they have no competing interests.

\section{Authors' contributions}

SV conceived of the case.

PAV and KL drafted the manuscript.

BM finalized the manuscript.

All authors have read and approved the final manuscript.

\section{Acknowledgements}

None

\section{References}

I. Motzer RJ, Bander NH, Nanus DM: Renal-cell carcinoma. N Engl J Med 1996, 335:865-875.

2. Hamid Y, Poller DN: Spontaneous regression of renal cell carcinoma: a pitfall in diagnosis of renal lesions. Journal of Clinical Pathology 1998, 5 I (4):334-337.

3. Lam JS, Shvarts O, Leppert JT, Figlin RA, Belldegrun AS: Renal Cell Carcinoma 2005: new frontiers in staging, prognostication and targeted molecular therapy. J Urol 2005, 173: 1853-1862.

4. Rabinovitch RA, Zelefsky MJ, Gaynor Jj, Fuks Z: Patterns of failure following surgical resection of renal cell carcinoma: implications of adjuvant local and systemic therapy. J Clin Oncol 1994, | 2:206-2|2.
5. Lam JS, Brenda A, Belldegrun AS: Evolving principles of surgical management and prognostic factors for outcome in renal cell carcinoma. J Clin Oncol 2006, 24(35):5565-5575.

6. Coppin C, Porzsolt F, Awa A, Kumpf J, Goldman A, Wilt T: Immunotherapy for advanced renal cell cancer. Cochrane database of systematic reviews 2004:Art. No: CD00I 425.

7. Bumpus HC: The apparent disappearance of pulmonary metastasis in a case of hypernephroma following nephrectomy. J Urol 1928, 20:|85-19|.

8. Lokich J: Spontaneous regression of metastatic renal cancer: case report and literature review. Am J Clin Oncol 1997, 20(4):4l6-4I8.

9. Papac RJ: Spontaneous regression of cancer. Cancer Treat Rev 1996, 22:395-423.

10. Nakajima T, Suzuki M, Ando S, lida T, Araki A, Fujisawa T, Kimura H: Spontaneous regression of bone metastasis from renal cell carcinoma; a case report. BMC Cancer 2006, 6: II.

II. Hammad AM, Paris GR, Van Heuven WA, Thompson IM, Fitzsimmons TD: Spontaneous regression of choroidal metastasis from renal cell carcinoma. American Journal of Ophthalmology 2003, 135(6):911-3.

12. Wyczólkowski M, Klima W, Bieda W, Walas K: Spontaneous regression of hepatic metastases after nephrectomy and metastasectomy of renal cell carcinoma. Urologia Internationalis 200I, 66(2): I19-20.
Publish with BioMed Central and every scientist can read your work free of charge

"BioMed Central will be the most significant development for disseminating the results of biomedical research in our lifetime. "

Sir Paul Nurse, Cancer Research UK

Your research papers will be:

- available free of charge to the entire biomedical community

- peer reviewed and published immediately upon acceptance

- cited in PubMed and archived on PubMed Central

- yours - you keep the copyright

Submit your manuscript here:

http://www.biomedcentral.com/info/publishing_adv.asp
BioMedcentral 